\title{
2,3,7,8-Tetrachlorodibenzo-p-dioxin suppresses the growth of human liver cancer HepG2 cells in vitro: Involvement of cell signaling factors
}

\author{
MASAYOSHI YAMAGUCHI ${ }^{1}$ and OLIVER HANKINSON ${ }^{1,2}$ \\ ${ }^{1}$ Department of Pathology and Laboratory Medicine, and ${ }^{2}$ Molecular Toxicology Program, David Geffen School of Medicine, \\ University of California, Los Angeles (UCLA), Los Angeles, CA 90095-1723, USA
}

Received April 16, 2018; Accepted June 27, 2018

DOI: $10.3892 /$ ijo.2018.4507

\begin{abstract}
The aryl hydrocarbon receptor (AHR) is transcriptionally active in the form of a heterodimer with the AHR nuclear translocator, which then binds to the xenobiotic responsive element. AHR was originally discovered via its ligand, the polychlorinated hydrocarbon, 2,3,7,8-tetrachlorodibenzo- $p$-dioxin (TCDD). In this study, we investigated whether TCDD regulates the growth of human liver cancer HepG2 cells in vitro. TCDD (0.1-100 nM) was found to exert suppressive effects on the colony formation and proliferation of HepG2 cells, and stimulatory effects on the death of HepG2 cells when the cells reached subconfluence. The effects of TCDD on the HepG2 cells were abolished by culture with CH223191, an inhibitor of AHR signaling. The effects of TCDD were dependent on the concentration of serum, which contains various signaling factors. The effects of TCDD were not potentiated by culture with tumor necrosis factor- $\alpha$, which activates the signaling of nuclear factor $-\kappa \mathrm{B}(\mathrm{NF}-\kappa \mathrm{B})$. The results of western blot analysis revealed that TCDD increased the protein levels of $\mathrm{p} 53, \mathrm{Rb}, \mathrm{p} 21$, and regucalcin, which are suppressors of the growth of tumor cells. Moreover, TCDD enhanced the NF- $\kappa \mathrm{B}$ p65, $\beta$-catenin, signal transducer and activator of transcription 3 (STAT3), Ras and Akt levels. Thus, the findings of this study indicate that TCDD may suppress liver cancer cell growth through various signaling pathways, mediated by AHR and its-related co-factors. Of note, the effects of TCDD were found to be potentiated by gemcitabine, which induces nuclear DNA damage in cancer cells, suggesting that their combined use may have potential as a suppressor of tumor cell growth.
\end{abstract}

Correspondence to: Dr Masayoshi Yamaguchi, Department of Pathology and Laboratory Medicine, David Geffen School of Medicine, University of California, Los Angeles (UCLA), 700 Tiverton Avenue, Los Angeles, CA 90095-1723, USA

E-mail: yamamasa11555@yahoo.co.jp

Key words: 2,3,7,8-tetrachlorodibenzo- $p$-dioxin, cell proliferation, cell death, colony formation, HepG2 cells, cell signaling, carcinogenesis

\section{Introduction}

The aryl hydrocarbon receptor (AHR) is a ligand-activated transcription factor belonging to the family of basic helix-loop-helix Per-Arnt-Sini transcription factors $(1,2)$. AHR is transcriptionally active in the form of a heterodimer with the AHR nuclear translocator (ARNT), which binds to xenobiotic responsive elements $(1,2)$. AHR was originally discovered through its binding to the polychlorinated aromatic hydrocarbons such as 2,3,7,8-tetrachlorodibenzo-p-dioxin (TCDD), polycyclic aromatase hydrocarbons, such as benzo[a] pyrene $(\mathrm{B}[\mathrm{a}] \mathrm{P})$ and polychlorinated biphenyls (PCBs) $(1,2)$. In recent years, many dietary compounds have been identified as AHR agonists (3-7). AHR signaling, which is regulated through various factors, may play a crucial role in the regulation of diverse cellular and biological processes. The canonical target genes for AHR are cytochrome P450 isoforms (CYP1A1, CYP1A2 and CYP1B1), which are implicated in the metabolism of xenobiotics and endogenous compounds, including eicosanoids (8). The AHR-dependent pathway is also involved in the process of chemically-induced toxicity and carcinogenesis through the production of free radicals and the conversion of pro-carcinogens to ultimate genotoxic carcinogens via metabolism by these enzymes $(8,9)$. Moreover, the xenobiotic and ligands of AHR are linked to various toxicities and pathologies in humans, including cancer (10-16). However, the molecular mechanisms responsible for the biological effects induced by non-genotoxic AHR ligands are poorly understood, and the mechanistic link between CYP induction and TCDD-mediated hepatotoxicity or immunotoxicity is complex $(17,18)$. Of note, a previous study on AHR-null mice have demonstrated that the AHR, in the absence of exogenous ligands, is involved in several physiological processes (19). These investigations demonstrate a pivotal role for AHR beyond xenobiotic metabolism (20).

The AHR interacts with signaling pathways, controlling not only the cellular response to toxic and carcinogenic compounds, but also physiological functions (21). The disorder of the fine homeostatic regulations of cell proliferation and apoptosis may lead to toxic processes, such as tumor promotion, immunosuppression and teratogenicity. AHR activation may lead to either the stimulation or inhibition of proliferation 
or apoptosis. The physiological function of the AHR in the absence of exogenous ligand may differ from its toxicological role after binding exogenous ligand. Mice expressing constitutively active AHR exhibited an enhanced development of liver tumors in a model of hepatocarcinogenesis (22). On the contrary, the AHR may also possess tumor suppressor activities in the liver (23). Notably, AHR deficiency exerts a profound effect on the hepatic system; thus, AHR-null mice have a reduced liver size and portal fibrosis (24-26). Other studies have indicated that TCDD can partially impair liver regeneration in mice following two-thirds partial hepatectomy (27). AHR signaling may serve to adjust liver repair and to block tumorigenesis by modulating stem-like cells and $\beta$-catenin signaling (28). Moreover, the AHR has been demonstrated to adjust liver regeneration after acute toxic injury and protect against liver carcinogenesis (29). From these findings, it has been proposed that non-toxic AHR agonists may be useful for preventing the growth of liver tumors.

We hypothesized that AHR signaling may inhibit the proliferation and stimulate the death of cancer cells, leading to the suppression of tumor growth. These effects of AHR signaling are not yet fully understood. The current study was thus undertaken to determine the effects of TCDD, an agonist of AHR, on the proliferation and death of human liver cancer HepG 2 cells in vitro. We demonstrate a novel finding that cell culture with TCDD at comparatively low levels suppresses the proliferation and stimulates the death of human liver cancer HepG2 cells in vitro, and that these effects are mediated through mechanistic pathways involved in AHR signaling activity and other related signaling factors.

\section{Materials and methods}

Materials and reagents. TCDD ( $>99.99 \%$ purity; Dow Chemicals Co., Midland, MI, USA) was dissolved in dimethylsulfoxide (DMSO) and stored in the dark at $-20^{\circ} \mathrm{C}$ until use. $\alpha$-minimum essential medium ( $\alpha$-MEM; with glutamine) and antibiotics [penicillin $(10,000 \mathrm{U} / \mathrm{ml})$ and streptomycin $(10,000 \mu \mathrm{g} / \mathrm{ml}) ; \mathrm{P} / \mathrm{S}]$ were purchased from Gibco Life Technologies Corp. (Grand Island, NY, USA). Fetal bovine serum (FBS) was obtained from Omega Scientific Inc. (Tarzana, CA, USA). 2-Methyl-2H-pyrazole-3-carboxylic acid (2-methyl-4-o-tolylazo-phenyl)-amide (CH223191) was obtained from Selleckchem Co. (Houston, TX, USA) and was dissolved in DMSO. Tumor necrosis factor- $\alpha$ (TNF- $\alpha$ ) was obtained from R\&D Systems (Minneapolis, MN, USA) and gemcytabine from Hospira, Inc. (Lake Forest, IL, USA) and were diluted in phosphate-buffered saline (PBS). Caspase-3 inhibitor (CAS 169332-60-9-Calbiochem), crystal violet and all other reagents were purchased from Sigma-Aldrich (St. Louis, MO, USA) unless otherwise specified.

Human liver cancer cells. We used human liver cancer HepG2 cells, which were obtained from the American Type Culture Collection (ATCC, Rockville, MD, USA). The HepG2 cell line was originally derived from a 15 -year-old child with primary hepatoblastoma (30). Although the HepG2 cells were not derived from hepatocellular carcinoma (30), this cell line was reported to be genetically the best model for hepatocellular carcinoma tumor studies (31).
Colony formation assay. The HepG2 cells were seeded into 6-well dishes at a density of $1 \times 10^{3} /$ well, and cultured in medium containing $10 \% \mathrm{FBS}, 1 \% \mathrm{P} / \mathrm{S}$ and $1 \%$ fungizone under $5 \% \mathrm{CO}_{2}$ at $37^{\circ} \mathrm{C}$ in the presence of either the vehicle (1\% DMSO) or TCDD (1 or $10 \mathrm{nM})$ for 14 days, when visible clones formed on the plates (32). The dishes were washed with PBS ( $2 \mathrm{ml}, 3$ times) and fixed with methanol $(0.5 \mathrm{ml} /$ well $)$ for $20 \mathrm{~min}$ at room temperature, and then washed 3 times with PBS. Finally, colonies were stained with $0.5 \%$ crystal violet for $30 \mathrm{~min}$ at room temperature. The stained cells were washed 5 times with PBS $(2 \mathrm{ml})$. The plates were air-dried for $2 \mathrm{~h}$ at room temperature. The colonies containing $>50$ cells were counted under a microscope (Nikon TMS, Tokyo, Japan). Data were represented as the numbers of colonies per well.

Crystal violet assay. Crystal violet is a basic dye, which stains cell nuclei, and spectrophotometric reading of color intensity is an indicator of DNA content, and cell number (33). For determining cell viability in relation to the colony formation, proliferation and death of HepG2 cells, an adaptation of the crystal violet staining procedure was applied, as follows: In the experiment for cell proliferation, the cells $\left(1 \times 10^{5} / \mathrm{ml}\right.$ per well) were seeded into 24 -well plates and cultured in $\alpha$-MEM (containing $10 \% \mathrm{FBS}, 1 \% \mathrm{P} / \mathrm{S}$ and $1 \%$ fungizone) in the presence of either the vehicle (1\% DMSO) or TCDD (1 or $10 \mathrm{nM})$ for 3 days. In the experiment for cell death, the cells $\left(1 \times 10^{5} / \mathrm{ml}\right.$ per well) were seeded into 24-well plates and cultured in $\alpha$-MEM (containing $10 \% \mathrm{FBS}, 1 \% \mathrm{P} / \mathrm{S}$ and $1 \%$ fungizone) for 3 days to reach subconfluency. They were then cultured for $24 \mathrm{~h}$ in the presence of either the vehicle (1\% DMSO) or TCDD (1 or $10 \mathrm{nM})$. The cells were washed with PBS and fixed with methanol for $20 \mathrm{~min}$ at room temperature, and then washed 3 times with PBS. Crystal violet solution $(0.5 \%$, in $20 \%$ methanol) was added to the fixed cells for $30 \mathrm{~min}$. Thereafter, the plates were immersed in running tap water for 15 min. After the plates had dried, $300 \mu 10.2 \%$ Triton X-100 (in distilled water) was added to each well followed by incubation at room temperature for $90 \mathrm{~min}$, and $100 \mu \mathrm{l}$ of the liquid content subsequently transferred to 96 -well microtiter plates. The absorbance (OD) was read on an ELX800 Universal Microplate Reader (Bio-Tek Instruments Inc.) at a wavelength of $570 \mathrm{~nm}$. Triton X-100 (0.2\% in distilled water) was used as a blank. The results are presented as absorbance.

Cell proliferation assay. The HepG2 cells (1x10 $/ \mathrm{ml}$ per well) were cultured using a 24 -well plate in $\alpha$-MEM (containing $10 \% \mathrm{FBS}, 1 \% \mathrm{P} / \mathrm{S}$ and $1 \%$ fungizone) in the presence of either the vehicle (1\% DMSO) or TCDD (0.1-1,000 nM) under $5 \% \mathrm{CO}_{2}$ and $37^{\circ} \mathrm{C}$ for 1-7 days (34). In separate experiments, the cells $\left(1 \times 10^{5} / \mathrm{ml}\right.$ per well) were cultured $\alpha$-MEM containing $10 \% \mathrm{FBS}, 1 \% \mathrm{P} / \mathrm{S}$ and $1 \%$ fungizone with or without TCDD ( 1 or $10 \mathrm{nM})$ in the presence of either the vehicle (1\% DMSO), $\mathrm{CH} 223191(1$ or $10 \mu \mathrm{M}), \mathrm{TNF}-\alpha(0.1$ or $1 \mathrm{ng} / \mathrm{ml})$, or gemcitabine $(0.1,1$ or $10 \mathrm{nM})$ for 3 days. The cells were then detached from each culture dish to determine the cell number as described below in the section 'Cell counting'.

Cell death assay. The HepG2 cells $\left(1 \times 10^{5} / \mathrm{ml}\right.$ per well) were cultured using a 24 -well plate in $\alpha$-MEM (containing $10 \% \mathrm{FBS}, 1 \% \mathrm{P} / \mathrm{S}$, and $1 \%$ fungizone) in the absence of 
TCDD for 3 days. On reaching subconfluence, the cells were cultured in the presence of either the vehicle (1\% DMSO) or TCDD (0.1-1,000 nM), with or without the caspase-3 inhibitor (10 $\mu \mathrm{M}), \mathrm{CH} 223191$ (1 or $10 \mu \mathrm{M})$, TNF- $\alpha(0.1$ or $1 \mathrm{ng} / \mathrm{ml})$, or gemcitabine $(0.1,1$ or $10 \mathrm{nM})$ for 24 or $48 \mathrm{~h}(35)$. The cells were then detached from each culture dish to determine the cell number as described below in the section 'Cell counting'.

Cell counting. To detach cells in each well, the culture dishes were incubated for $2 \mathrm{~min}$ at $37^{\circ} \mathrm{C}$ after the addition of a solution ( $0.1 \mathrm{ml}$ per well) of $0.05 \%$ trypsin plus EDTA in $\mathrm{Ca}^{2+} / \mathrm{Mg}^{2+}$-free PBS, and the cells were detached through pipetting after the addition of DMEM $(0.9 \mathrm{ml})$ containing $10 \% \mathrm{FBS}$ and $1 \% \mathrm{P} / \mathrm{S}$ as previously described $(34,35)$. Medium containing the suspended cells $(0.1 \mathrm{ml})$ was mixed by the addition of $0.1 \mathrm{ml}$ of $0.5 \%$ trypan blue staining solution. The number of viable cells was counted under a microscope (Olympus MTV-3) with a Hemocytometer (Sigma-Aldrich) using a cell counter (Line Seiki H-102P; Line Seiki Co., Ltd., Tokyo, Japan). For each dish, we took the average of two counts. Cell numbers are shown as number per well.

Western blot analysis. In the cell proliferation experiments, the HepG 2 cells were plated in 100x21 mm dishes at a density of $1 \times 10^{6}$ cells/dish in $10 \mathrm{ml}$ of $\alpha$-MEM containing $10 \% \mathrm{FBS}$, $1 \% \mathrm{P} / \mathrm{S}$ and $1 \%$ fungizone, and the cells were then cultured in the presence of either the vehicle (1\% DMSO) or TCDD ( 1 or $10 \mathrm{nM}$ ) for 3 days. In the cell death experiment, the cells $\left(1 \times 10^{6} / \mathrm{ml} / \mathrm{dish}\right)$ were seeded in $100 \times 21 \mathrm{~mm}$ dishes and cultured in $10 \mathrm{ml}$ of $\alpha$-MEM (containing $10 \% \mathrm{FBS}, 1 \% \mathrm{P} / \mathrm{S}$ and $1 \%$ fungizone) for 3 days to reach subconfluency. They were then cultured for $24 \mathrm{~h}$ in the presence of either the vehicle (1\% DMSO) or TCDD (1 or $10 \mathrm{nM})$. The cells were washed 3 times with cold PBS and removed from the dish by scraping in cell lysis buffer (Cell Signaling Technology, Danvers, MA, USA) supplemented with inhibitors of protease and protein phosphatase (Roche Diagnostics, Indianapolis, IN, USA). The lysates were then centrifuged at $17,000 \times \mathrm{g}$ at $4^{\circ} \mathrm{C}$ for $10 \mathrm{~min}$. The protein concentrations of the supernatants were determined using the Bio-Rad Protein Assay Dye (Bio-Rad Laboratories, Inc., Hercules, CA, USA) with bovine serum albumin as a standard. The supernatant was stored at $-80^{\circ} \mathrm{C}$ until use. Samples of $40 \mu \mathrm{g}$ of supernatant protein per lane were separated by $12 \%$ SDS polyacrylamide gel electrophoresis (SDS-PAGE), and transferred onto nylon membranes for immunoblotting with specific antibodies. Polyclonal AHR antibody sheep IgG was obtained from R\&D Systems (cat. no. AF6697). Other antibodies to signaling proteins, including caspase-3 (cat. no. 9662), signal transducer and activator of transcription 3 (STAT3) (cat. no. 12640), Ras (cat. no. 14429), Akt (cat. no. 9272), mitogen-activated protein kinase (MAPK) (cat. no. 4695), $\beta$-actin (cat. no. 3700), Rb (cat. no. 9309) and p21 (cat. no. 2947) were obtained from Cell Signaling Technology (Danvers, MA, USA), and CYP1A1 (cat. no. sc-25304), nuclear factor (NF)- $\mathrm{B}$ p65 (cat. no. sc-109), $\beta$-catenin (cat. no. sc-39350) and p53 (cat. no. sc-126) were obtained from Santa Cruz Biotechnology, Inc. (Santa Cruz, CA, USA) (36). Rabbit anti-regucalcin antibody was obtained from Abcam (Cambridge, MA, USA; diluted 1:1,000; cat. no. ab213459), and it was used as previously described $(36,37)$.
The membranes were incubated with one of the primary antibodies (diluted 1:1,000) overnight at $4^{\circ} \mathrm{C}$, followed by horseradish peroxidase-conjugated secondary antibodies (cat. no. mouse sc-2005 or rabbit sc-2305; Santa Cruz Biotechnology, Inc.; diluted 1:2,000). For the AHR antibody, we used sheep IgG horseradish peroxidase-conjugated antibody (R\&D Systems; diluted 1:1,000; cat. no. HAF016). The immunoreactive blots were visualized with a SuperSignal West Pico Chemiluminescent Substrate detection system (Thermo Fisher Scientific, Rockford, IL, USA) according to the manufacturer's instructions. $\beta$-actin (diluted 1:2,000; cat. no. 3700; Cell Signaling Technology) was used as a loading control. A minimum of 3 blots from independent experiments were scanned on an Epson Perfection 1660 Photo scanner, and bands quantified using ImageJ software.

Statistical analysis. Statistical significance was determined using GraphPad InStat version 3 for Windows XP (GraphPad Software Inc., La Jolla, CA, USA). Multiple comparisons were performed by one-way analysis of variance (ANOVA) with the Tukey-Kramer multiple comparisons post hoc test for parametric data as indicated. A value of $\mathrm{P}<0.05$ was considered to indicate a statistically significant difference.

\section{Results}

TCDD suppresses on colony formation of HepG2 cells. To determine the effects of TCDD on the colony formation of HepG2 cells in vitro, the HepG2 cells were cultured in the presence of TCDD ( 1 or $10 \mathrm{nM}$ ) for 14 days, when visible clones were formed on the plates (Fig. 1). Crystal violet is a basic dye that stains cell nuclei (33). Colony formation with $>50$ nuclei by estimation with crystal violet staining was suppressed by culture with TCDD (1 or $10 \mathrm{nM})$, as shown in Fig. 1.

TCDD suppresses the growth and proliferation of HepG2 cells. Cell growth with increasing periods of culture is shown in Fig. 2A. Cells reached subconfluency in culture for 3 days and to confluency after 4-7 days of culture in 24-well plates. At 3 days after culture in the presence or absence of TCDD (1 or $10 \mathrm{nM}$ ), the cell density was also determined by measuring the absorbance of crystal violet in the fixed cells (Fig. 2B and C). The spectrophotometer reading of color intensity by staining with crystal violet is an indicator of the DNA content and cell number (33). Cell growth was clearly suppressed by culture with TCDD (Fig. 2B and C). As shown in Fig. 2D and E, representing growth after 3 and 7 days in culture, respectively, the suppression of cell proliferation occurred at a concentration of TCDD as low as $0.1 \mathrm{nM}$

TCDD stimulates the death of HepG2 cells. To investigate whether TCDD stimulates the death of HepG2 cells in vitro, the cells were cultured for 3 days to reach subconfluency and then exposed to TCDD ( 1 or $10 \mathrm{nM}$ ) for a further day. TCDD treatment led to cell death. As shown in the images in Fig. 3A and by the absorbance (Fig. 3B), TCDD clearly had an effect on cell counts at a concentration as low as $0.1 \mathrm{nM}$ both at 24 and $48 \mathrm{~h}$ of treatment after the cells reached subconfluency (Fig. 3C and E). In separate experiments, on reaching subconfluency after culture for 3 days, the cells were cultured 
A

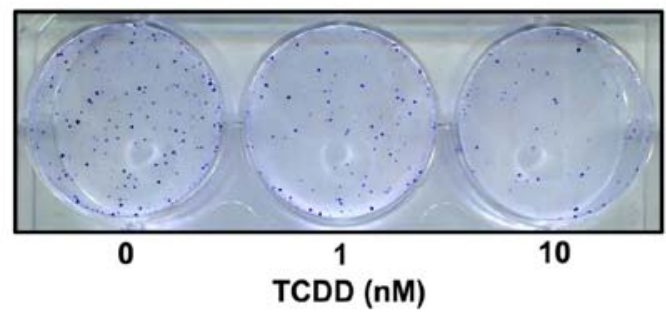

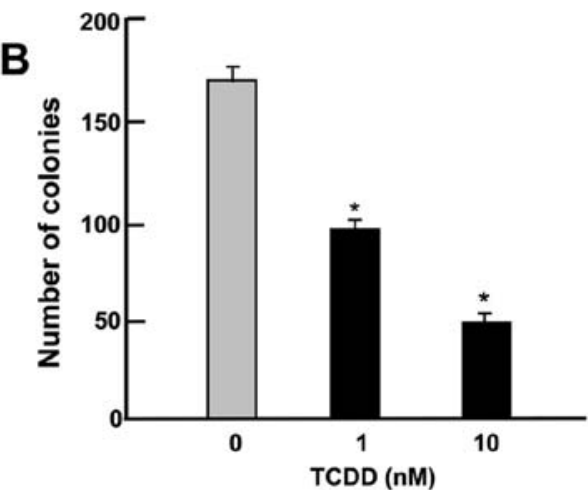

Figure 1.2,3,7,8-Tetrachlorodibenzo-p-dioxin (TCDD) suppresses colony formation of HepG2 cells in vitro. Cells (1x10 $3 /$ well) were seeded into 6-well dishes and cultured in $\alpha$-MEM containing 10\% FBS in the presence of either vehicle (1\% DMSO) or TCDD (1 or $10 \mathrm{nM})$ for 14 days when visible clones formed. The colonies were washed with PBS and fixed with methanol. Colonies were stained with $0.5 \%$ crystal violet. Stained cells are represented as (A) images, and (B) colonies containing more than 50 cells were counted under a microscope. ${ }^{*} \mathrm{P}<0.001$ vs. control (gray bar), determined by one-way ANOVA with the Tukey-Kramer post hoc test.
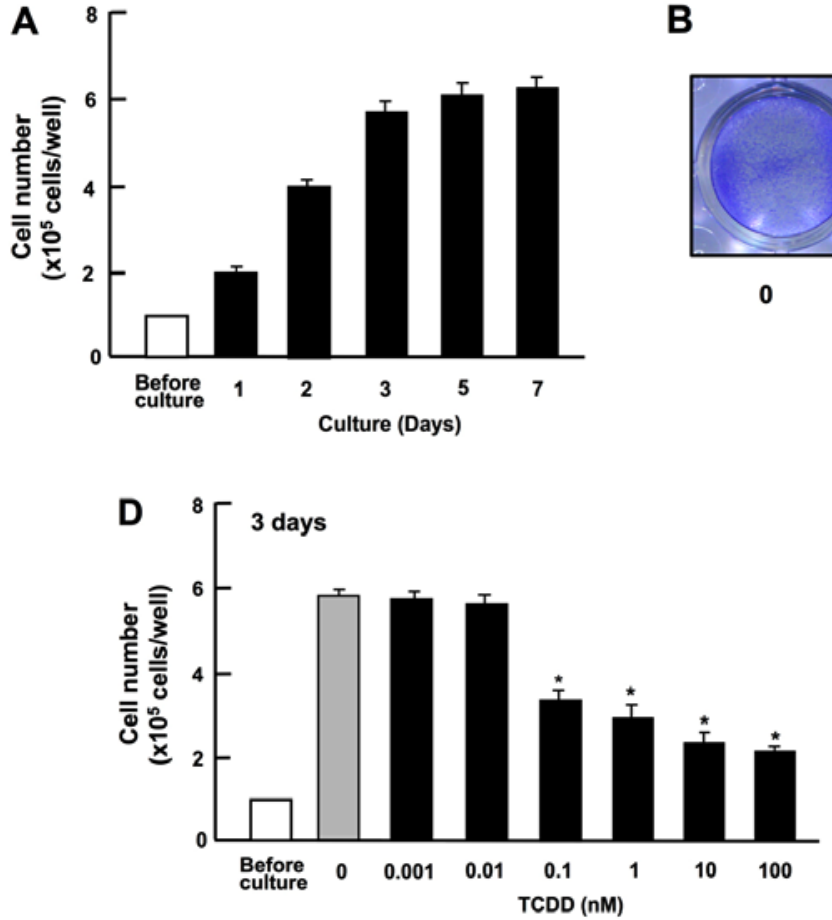

B

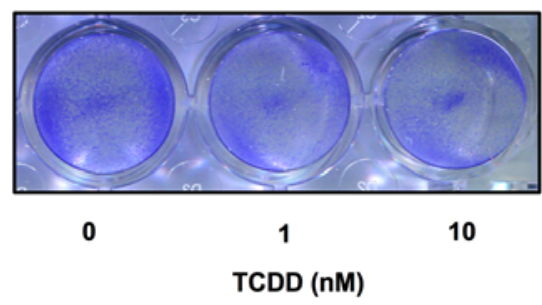

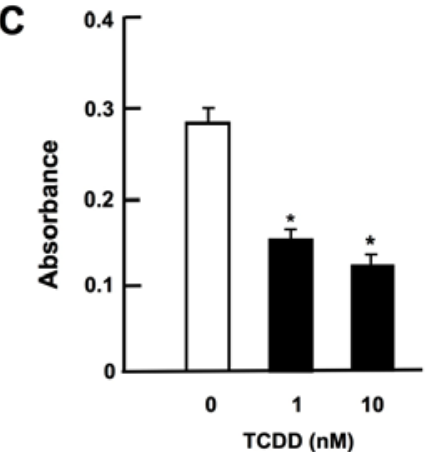

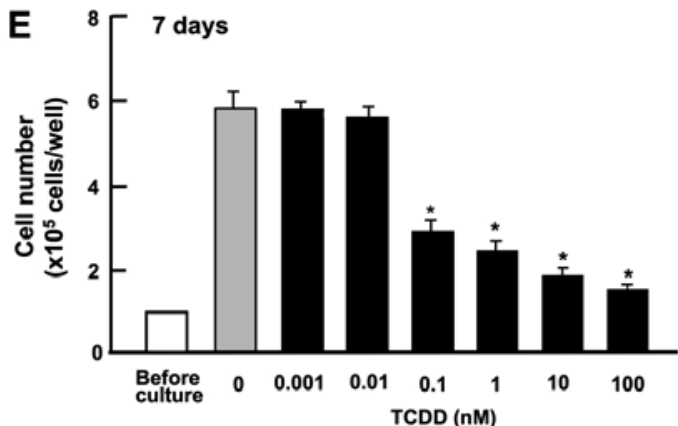

Figure 2. 2,3,7,8-Tetrachlorodibenzo-p-dioxin (TCDD) suppresses the proliferation of HepG2 cells in vitro. (A) Cells (1x10 $0^{5}$ cells/well in 24-well plates) were cultured in $\alpha$-MEM containing 10\% FBS for 1-7 days. (B and C) Cells were cultured in $\alpha$-MEM for 3 days in the presence of either the vehicle or TCDD (1 and $10 \mathrm{nM})$, and cells were stained with $0.5 \%$ crystal violet. Stained cells are shown in (B) and the absorbance in $(\mathrm{C})$. In a separate experiment, cells $\left(1 \times 10^{5}\right.$ cells well) were cultured in $\alpha$-MEM containing either the vehicle or TCDD (0.001-100 nM) for 3 days (D) or 7 days (E). After culture, the number of attached cells was counted. Data are presented as the means \pm SD obtained from 8 wells of 2 replicate plates per data set using different dishes and cell preparations. ${ }^{*} \mathrm{P}<0.001$ vs. control (grey bar), determined by one-way ANOVA with the Tukey-Kramer post hoc test.

in the presence of a caspase-3 inhibitor $(10 \mu \mathrm{M})$ (see Materials and methods) for 24 (Fig. 3D) or $48 \mathrm{~h}$ (Fig. 3F). The decrease in cell number induced by TCDD ( 1 or $10 \mathrm{nM})$ was eliminated by treatment with the inhibitor of caspase-3. Moreover, the results of western blot analysis revealed that the caspase- 3 levels were increased by culture with TCDD (1 or $10 \mathrm{nM}$ ) (Fig. 3G). The activation of caspase-3 induces DNA fragmentation related to apoptotic cell death (34). Thus, TCDD-induced cell death was likely due, at least in part, to an increase in the caspase-3 levels.
Characterization of the effects of TCDD on the proliferation and death of HepG2 cells. To determine the mechanisms responsible for the TCDD-induced suppression of the proliferation and the stimulation of the death of $\mathrm{HepG} 2$ cells, the cells were cultured in the presence of $\mathrm{CH} 223191$, an inhibitor of AHR signaling (31). Western blot analysis identified AHR and AHR-inducible CYP1A1, representing a member of the cytochrome P450 superfamily of enzymes $(1,2)$, in the HepG2 cells (Fig. 4A). TCDD (1 or $10 \mathrm{nM})$ induced a decrease in the levels of AHR and a corresponding increase in the levels of 
A
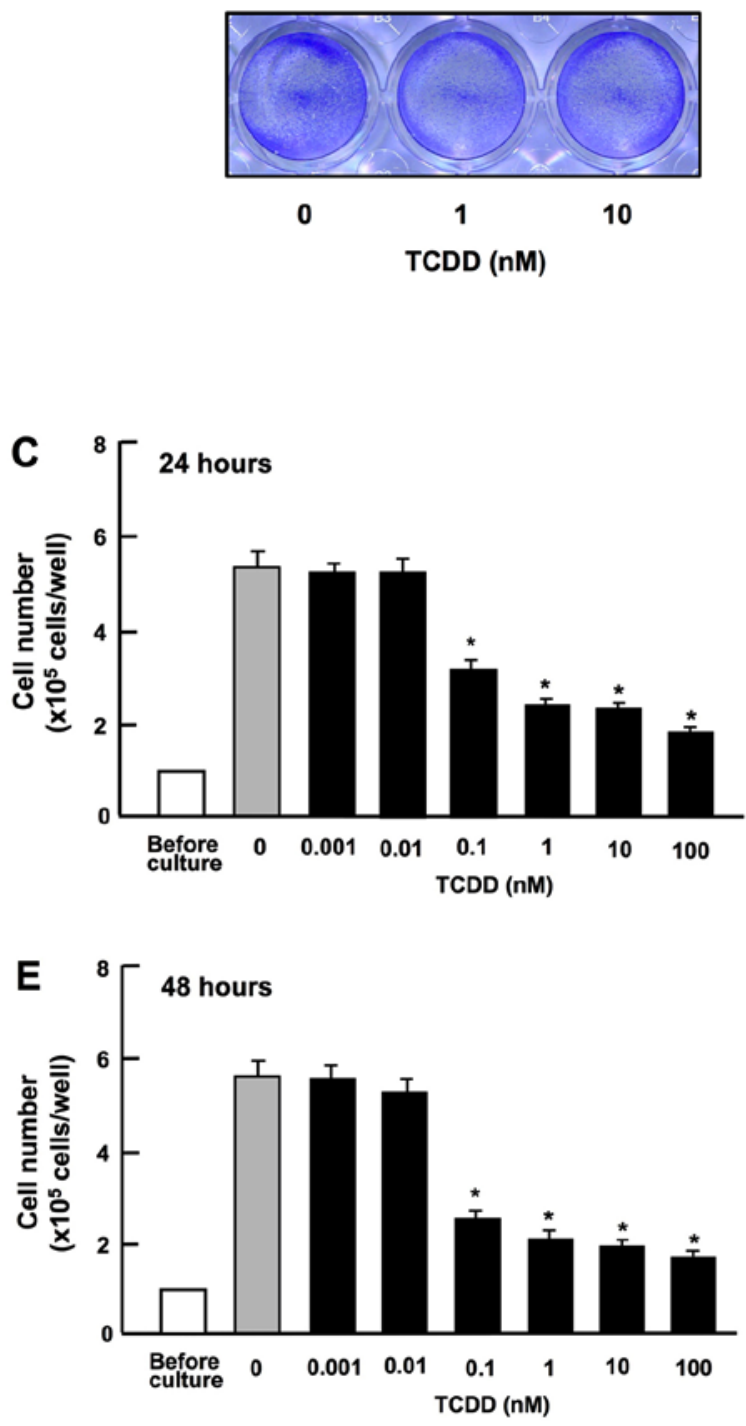

B
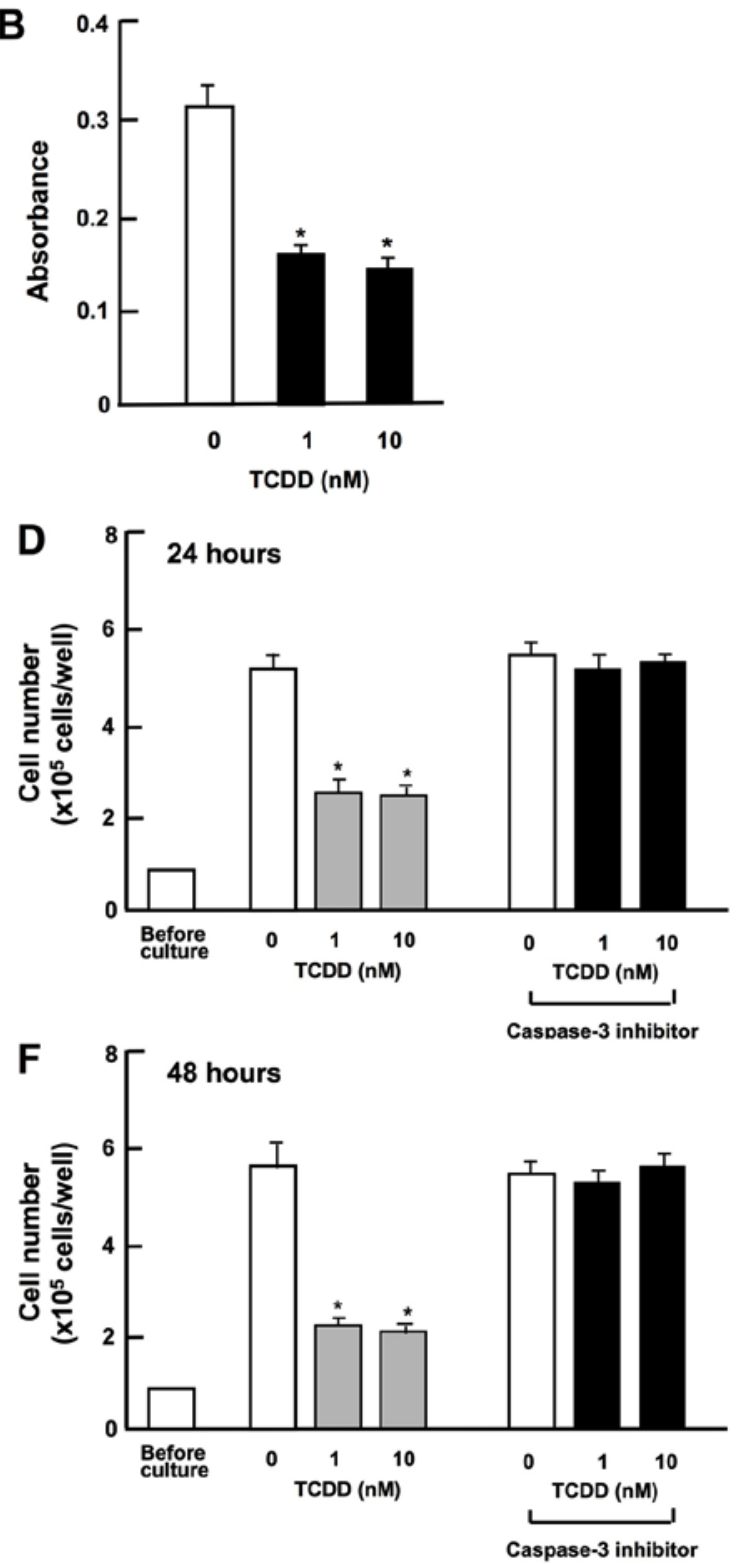

G

TCDD (nM)

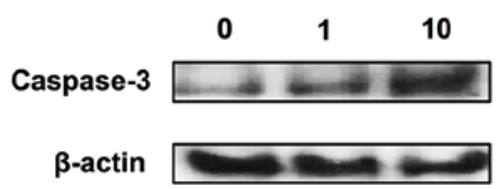

Figure 3. 2,3,7,8-Tetrachlorodibenzo-p-dioxin (TCDD) stimulates the death of HepG2 cells in vitro. (A and B) Cells (1x10 cells in $1 \mathrm{ml}$ per in 24-well plates) were cultured in $\alpha$-MEM for 3 days to reach subconfluency, and then cultured in $\alpha$-MEM containing $10 \%$ FBS in the presence of either the vehicle (1\% DMSO) or TCDD (1 or $10 \mathrm{nM})$ for $24 \mathrm{~h}$, and stained with crystal violet. Stained cells are shown in (A) and absorbance in (B). In separate experiments, subconfluent cells were cultured in the presence of either the vehicle or TCDD (0.001-100 nM) for (C) 24 or (E) $48 \mathrm{~h}$, or were cultured for (D) 24 or (F) $48 \mathrm{~h}$ in the presence of either vehicle or TCDD (1 or $10 \mathrm{nM})$ with or without caspase-3 inhibitor $(10 \mu \mathrm{M})$. Following culture, the number of cells attached on dish was counted. (G) A total of $1 \times 10^{6}$ cells were seeded in $100 \times 21 \mathrm{~mm}$ dishes and cultured in $\alpha$-MEM for 3 days, to reach subconfluency, and then exposed to either the vehicle or TCDD ( 1 or $10 \mathrm{nM})$ for $24 \mathrm{~h}$. Following culture, the cell lysate (40 $\mu \mathrm{g}$ protein per lane) were applied to SDS-PAGE for western blot analysis using specific antibodies against casapase-3. Data represent results obtained from 3 independent experiments using different cell preparations. Data of cell number (C-F) are presented as the means \pm SD obtained from 8 wells of 2 replicate plates per data set using different dishes and cell preparations. "P<0.001 vs. control (without TCDD), determined by one-way ANOVA with the Tukey-Kramer post hoc test.

CYP1A1 in the cytosol of the HepG2 cells (Fig. 4A). Culture with $\mathrm{CH} 223191(1$ or $10 \mu \mathrm{M})$ alone did not exert a significant effect on the proliferation (Fig. 4B) or death (Fig. 4C) of the HepG2 cells. The suppressive effect of TCDD (1 or $10 \mathrm{nM})$ on the proliferation and the stimulatory effect of TCDD (1 or $10 \mathrm{nM}$ ) on cell death with decrease in attached HepG2 cells were not caused in the presence of $\mathrm{CH} 223191$, although the effects of TCDD were not completely blocked by the 
A
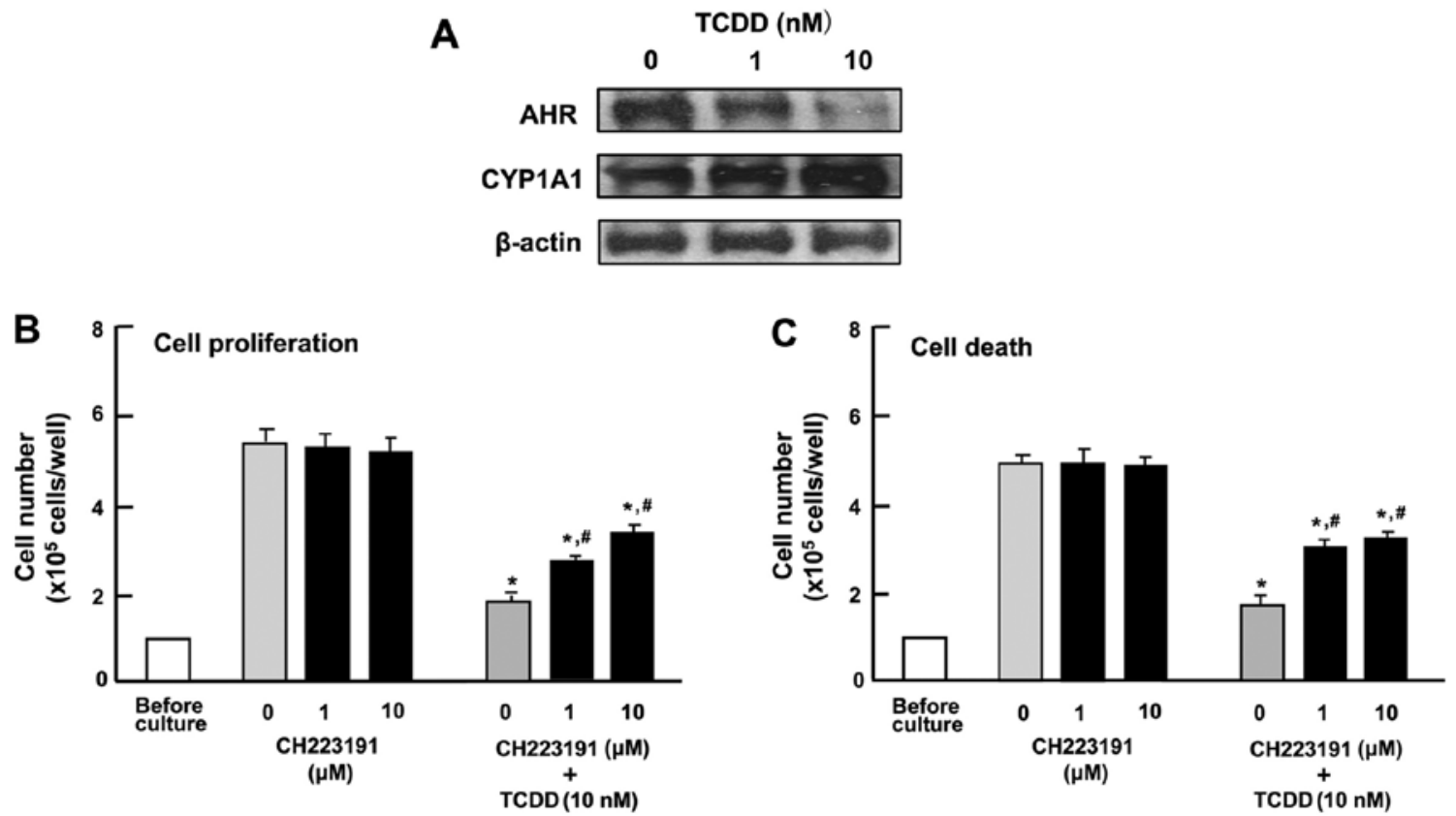

Figure 4. Involvement of the aryl hydrocarbon receptor (AHR) in mediating the effects of 2,3,7,8-tetrachlorodibenzo-p-dioxin (TCDD) on the proliferation and death of HepG2 cells. (A) Cells (1x10 $/ \mathrm{ml} / \mathrm{dish})$ were seeded into $100 \times 21 \mathrm{~mm}$ dishes and cultured in $\alpha$-MEM containing $10 \%$ FBS in the presence of either the vehicle (1\% DMSO) or TCDD (1 or $10 \mathrm{nM}$ ) for 3 days to reach subconfluency. Cell lysates (40 $\mu$ g protein per lane) were applied to SDS-PAGE for western blot analysis, using specific antibodies against AHR or CYP1A1. Data represent results obtained from 3 independent experiments using different cell preparations. (B) Cells ( $1 \times 10^{5}$ cells/per well of $\mathrm{ml}$ in 24 -well plates) were cultured in $\alpha$-MEM containing either the vehicle or TCDD (10 nM) for 3 days in the presence of $\mathrm{CH} 223191(1$ or $10 \mu \mathrm{M})$. (C) Cells ( $1 \times 10^{5}$ cells/per well of $\mathrm{ml}$ in 24 -well plates) were cultured in $\alpha$-MEM for 3 days to reach subconfluency. They were then were cultured in $\alpha$-MEM containing either the vehicle or CH223191 ( 1 or $10 \mu \mathrm{M}$ ). After $1 \mathrm{~h}$, TCDD (10 nM) was added to the medium and the cells cultured for a further $23 \mathrm{~h}$. The numbers of attached cells were then counted. Data are presented as the means \pm SD obtained from 8 wells of 2 replicate plates per data set using different dishes and cell preparations. ${ }^{*} \mathrm{P}<0.001$ vs. control (without TCDD or $\mathrm{CH} 223191$ ). ${ }^{*} \mathrm{P}<0.01$ as compared with the value obtained from TCDD alone, determined by one-way ANOVA with the Tukey-Kramer post hoc test.
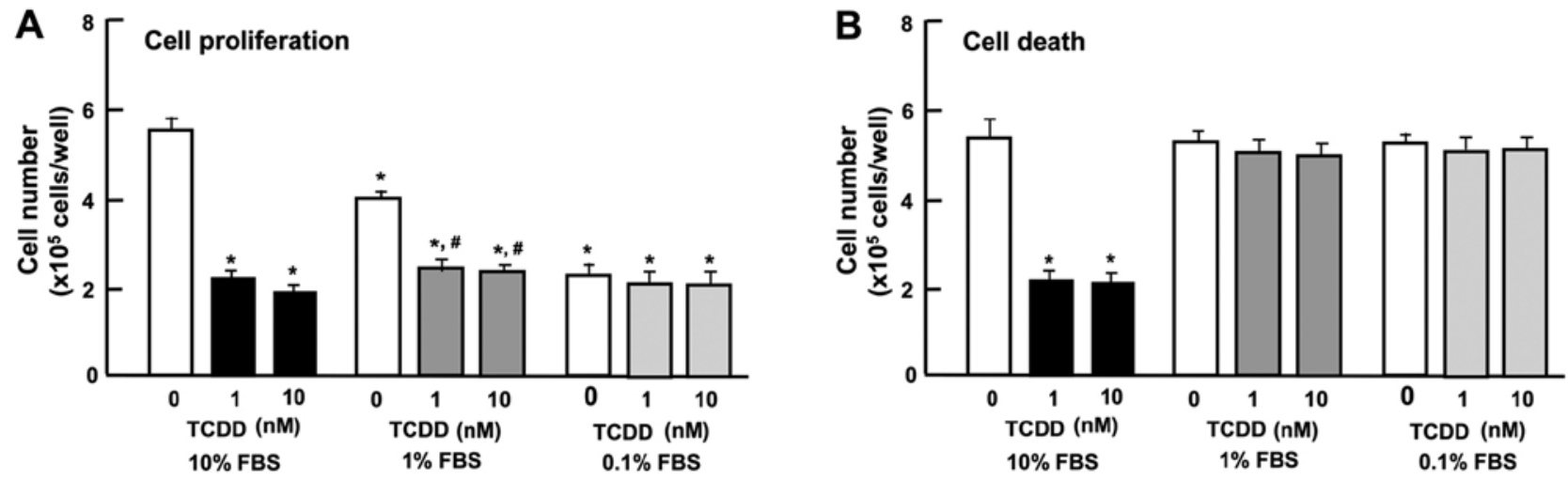

Figure 5. Effects of 2,3,7,8-tetrachlorodibenzo-p-dioxin (TCDD) on the proliferation and death of HepG2 cells are dependent on the concentrations of FBS in vitro. (A) Cells $\left(1 \times 10^{5}\right.$ cells/per well of $\mathrm{ml}$ in 24 -well plates) were cultured in $\alpha$-MEM containing different concentrations $(10,1$ or $0.1 \%)$ of FBS in the presence of either the vehicle (1\% DMSO) or TCDD $(1$ or $10 \mathrm{nM})$ for 3 days. (B) Cells $\left(1 \times 10^{5}\right.$ cells/per well of ml in 24 -well plates) were cultured in $\alpha$-MEM containing 10\% FBS for 3 days, and the subconfluent cells were then washed with PBS. The cells were then cultured for $24 \mathrm{~h}$ in $\alpha$-MEM containing different concentrations $(10,1$ or $0.1 \%)$ of FBS in the presence of either vehicle or TCDD $(1$ or $10 \mathrm{nM})$. After culture, the number of attached cells were counted. Data are presented as the means \pm SD obtained from 8 wells of 2 replicate plates per data set using different dishes and cell preparations. ${ }^{*} \mathrm{P}<0.001 \mathrm{vs}$. control (the values obtained from culture with $10 \%$ FBS without TCDD). ${ }^{~} \mathrm{P}<0.001$ as compared with the value obtained from culture with $1 \%$ FBS without TCDD, determined by one-way ANOVA with the Tukey-Kramer post hoc test.

inhibitor (Fig. 4B and C). These findings suggested that the effects of TCDD on the proliferation and death of HepG2 cells are at least partly mediated through AHR signaling.

The expression of AHR has been shown to be regulated by serum and mitogenic growth factors in murine $3 \mathrm{~T} 3$ fibroblasts (38). In this study, we thus examined the effect of the serum concentration of TCDD on the proliferation and death of HepG2 cells in vitro. Reduced serum concentrations resulted in a diminished proliferation of HepG2 cells. The suppressive effects of TCDD (1 or $10 \mathrm{nM}$ ) on cell proliferation were not further enhanced by reducing the serum concentration from 10 to 1 or $0.1 \%$ (Fig. 5A). Cell death was not altered with increasing concentrations (0.1, 1 or 10\%) of FBS (Fig. 5B). Moreover, the stimulatory effects of TCDD (1 or $10 \mathrm{nM})$ on 

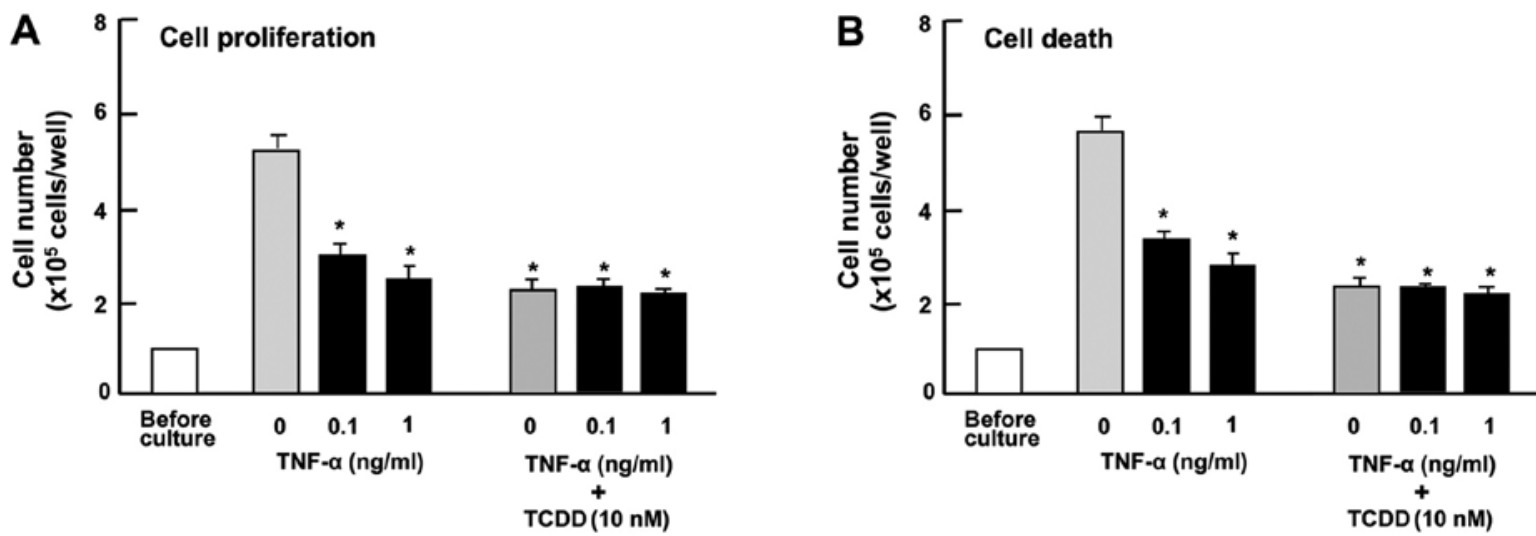

Figure 6. Effect of 2,3,7,8-tetrachlorodibenzo-p-dioxin (TCDD) on the proliferation and death of HepG2 cells in the presence of TNF- $\alpha$. (A) Cells (1x $10^{5}$ cells/per well in 24-well plates) were cultured in $\alpha$-MEM containing 10\% FBS in the presence of either the vehicle (1\% DMSO) or TCDD (10 nM) for 3 days in the

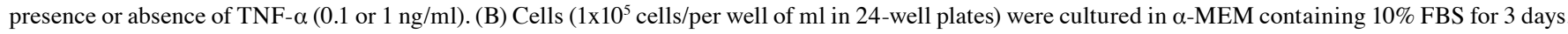
and the cells, upon reaching subconfluency after 3 days, were then cultured in $\alpha$-MEM containing $10 \%$ FBS in the presence of either the vehicle or TCDD $(10 \mathrm{nM})$ with or without TNF- $\alpha(0.1 \mathrm{or} 1 \mathrm{ng} / \mathrm{ml})$ for $24 \mathrm{~h}$. Following culture, the numbers of attached cells were counted. Data are presented as the means \pm SD obtained from 8 wells of 2 replicate plates per data set using different dishes and cell preparations. ${ }^{~} \mathrm{P}<0.001$ vs. control (without both TNF- $\alpha$ and TCDD), determined by one-way ANOVA with the Tukey-Kramer post hoc test.

A

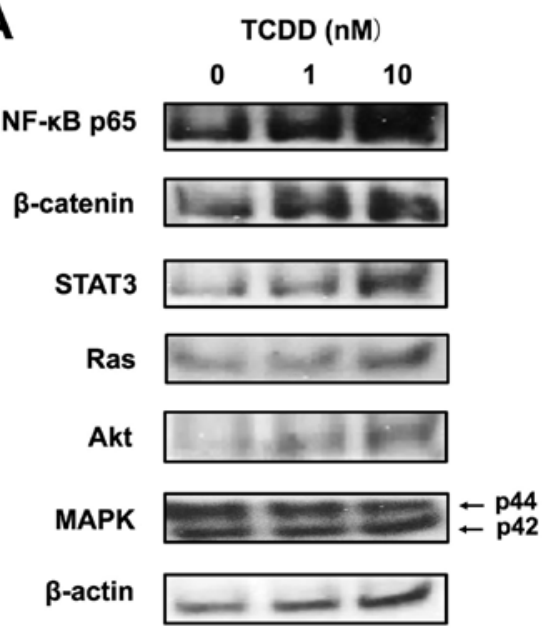

B

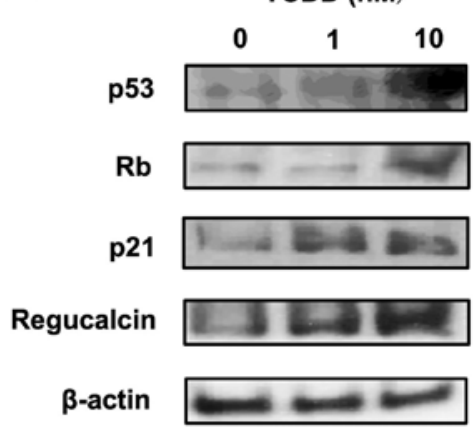

Figure 7. 2,3,7,8-Tetrachlorodibenzo-p-dioxin (TCDD) regulates the expression of proteins linked to various signaling pathways in HepG2 cells in vitro. Cells $\left(1 \times 10^{6}\right.$ cells/per dish) were cultured in $\alpha$-MEM containing $10 \%$ FBS in the presence of either vehicle (1\% DMSO) or TCDD (1 or $10 \mathrm{nM}$ ) for 3 days. After culture, the cells were removed from the dish after addition of cell lysis buffer containing protease and protein phosphatase inhibitors. Resulting cell lysates were centrifuged to obtain the cytosolic supernatant. Samples of $40 \mu \mathrm{g}$ of the supernatant protein per lane were separated by SDS-PAGE and transferred to nylon membranes for western blot analysis using specific antibodies against various proteins. (A) Cell signaling-related proteins; (B) tumor suppressor proteins. Data represent results obtained from 3 independent experiments using different cell preparations.

cell death with decrease in attached cells were not exhibited with a lower concentration $(0.1$ or $1 \%)$ of FBS (Fig. 5B). These results indicate that the TCDD-induced suppression of cell proliferation and stimulation of cell death were dependent on the concentration of serum, which contains various growth factors, hormones and cytokines.

TNF- $\alpha$ has been shown to modulate the effects of AHR ligands on cell proliferation and expression of cytochrome P450 enzymes in rat liver 'stem-like' cells (39). In our experiments, TNF- $\alpha(0.1$ or $1 \mathrm{ng} / \mathrm{ml})$ suppressed the proliferation of HepG2 cells (Fig. 6A) and reduced the number of attached cells, indicating increased cell death (Fig. 6B) in vitro. The suppressive effects of TCDD $(10 \mathrm{nM})$ on the proliferation and the promoting effects on the death of HepG2 cells were not potentiated by TNF- $\alpha(0.1$ or $1 \mathrm{ng} / \mathrm{ml})$ (Fig. 6), suggesting that these effects of TCDD are at least partially mediated through the activation of $\mathrm{NF}-\kappa \mathrm{B}$ signaling.

TCDD regulates protein levels linked to certain key signaling pathways in HepG2 cells. To further investigate the mechanisms of action of TCDD, we examined whether TCDD affects the expression of key transcription factors and other proteins related to important signaling pathways, using western blot analysis. TCDD $(10 \mathrm{nM})$ increased the protein levels of NF- $\mathrm{B}$ p65, $\beta$-catenin and STAT3, which are transcription factors linked to cell signaling (Fig. 7A). TCDD (10 nM) also elevated the levels of Ras and Akt, but did not alter the level of MAPK, which acts downstream of Ras and Akt signaling (Fig. 7A). Of note, TCDD (10 nM) markedly increased the expression levels of $\mathrm{p} 53, \mathrm{Rb}$, 

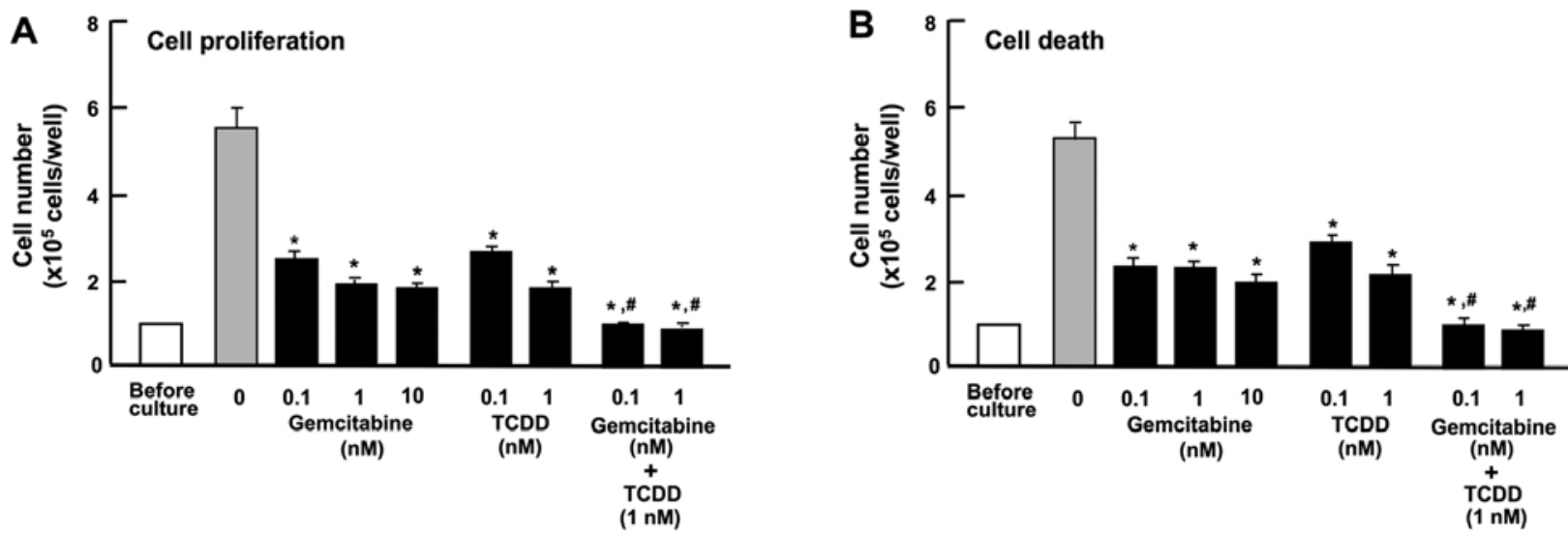

Figure 8. Combination of 2,3,7,8-tetrachlorodibenzo-p-dioxin (TCDD) and gemcitabine reveals different mechanisms affecting the proliferation and death of HepG2 cells in vitro. (A) Cells ( $1 \times 10^{5}$ cells/per well in 24-well plates) were cultured in $\alpha$-MEM containing $10 \%$ FBS in the presence of either the vehicle (1\% DMSO), gemcitabine $(0.1,1$ or $10 \mathrm{nM})$, TCDD $(0.1$ or $1 \mathrm{nM})$, or gemcitabine $(0.1$ or $1 \mathrm{nM})$ plus TCDD $(1 \mathrm{nM})$ for 3 days. (B) Cells (1x10 cells/per well in 24-well plates) were cultured in $\alpha$-MEM containing 10\% FBS for 3 days, and the cells on reaching subconfluency were then cultured for $24 \mathrm{~h}$ in $\alpha$-MEM containing $10 \% \mathrm{FBS}$ in the presence of either the vehicle, gemcitabine $(0.1,1$ or $10 \mathrm{nM})$, TCDD $(0.1$ or $1 \mathrm{nM})$, or gemcitabine $(0.1$ or $1 \mathrm{nM})$ plus TCDD $(1 \mathrm{nM})$. Following culture, the numbers of attached cells were counted. Data are presented as the means \pm SD obtained from 8 wells of 2 replicate plates per data set using different dishes and cell preparations. " $\mathrm{P}<0.001$ vs. control (without gemcitabine and TCDD). ${ }^{~} \mathrm{P}<0.001$ as compared with the value obtained from gemcitabine or TCDD alone, determined by one-way ANOVA with the Tukey-Kramer post hoc test.

p21 and regucalcin, which are suppressors of tumor cell growth $(40,41)$ (Fig. 7B).

The combination of TCDD and gemcitabine exerts independent effects on the proliferation and death of HepG2 cells. Gemcitabine, an antitumor drug, the action of which is not implicated in AHR signaling, is known to suppress the proliferation and stimulate the death of cancer cells by inducing nuclear DNA damage (42). In this study, the effects of TCDD on the proliferation and death of HepG2 cells were compared with those of gemcitabine (Fig. 8). Gemcitabine $(0.1,1$ or $10 \mathrm{nM})$ suppressed cell proliferation (Fig. 8A) and decreased the number of attached cells, indicating increased cell death (Fig. 8B). TCDD (0.1 or $1 \mathrm{nM}$ ) also suppressed cell proliferation and stimulated cell death; the effects of TCDD were significantly enhanced in the presence of gemcitabine (0.1 or $1 \mathrm{nM}$ ) (Fig. 8). These findings suggest that the mode of action of TCDD as regards cell proliferation and death differs from that of gemcitabine (42). The combination of TCDD and gemcitabine may have a potential additive suppressive effect on the growth of tumor cells, suggesting a novel strategy in the treatment of liver cancer.

\section{Discussion}

AHR plays manifold roles in cell differentiation, proliferation and organ homeostasis, including in the liver (29). The depletion of AHR induces dedifferentiation and pluripotency in normal and transformed cells (29). The activation of AHR has been shown to promote the development of liver tumors in a model of hepatocarcinogenesis $(22,24-26)$. This receptor may also possess tumor suppressor activities in the liver $(23,27,28)$. TCDD is a potent activator of AHR signaling. In this study, we demonstrated that TCDD at a comparatively lower concentration, suppressed the formation of colonies and the proliferation of human liver cancer HepG2 cells in vitro, and stimulated the death of these cells. The TCDD-induced suppression of colony formation resulted from both the suppressed proliferation and the enhanced death of HepG2 cells. The effects of TCDD on the proliferation and death of HepG2 cells were diminished in the presence of $\mathrm{CH} 223191$, an inhibitor of AHR signaling (31), supporting the view that observed TCDD effects are at least partly mediated through the AHR signaling pathway.

AHR expression has been shown to be regulated by serum, containing mitogenic growth factors in murine 3T3 fibroblasts (38). AHR expression has been shown to be diminished by culture in a lower concentration of serum (38). Ligand activated platelet-derived growth factor receptor and basic fibroblast growth factor receptor, as well as an ectopically expressed tyrosine kinase, have been shown to lead to an enhancement of AHR expression in the absence of serum (38). Tyrosine kinase signaling may be necessary for AHR expression (38). Of note, in this study, we found that the suppressive effects of TCDD on the proliferation in HepG2 cells were not enhanced with the reduction of the serum concentration in vitro. In addition, the stimulatory effects of TCDD on the death of HepG2 cells were eliminated when the cells were cultured with lower concentrations of serum. Thus, the TCDD-induced suppression of the proliferation and the stimulation of the death of HepG2 cells were dependent on the concentration of serum, which contains various growth factors, hormones and cytokines.

TNF- $\alpha$, which activates NF- $\kappa B$ signaling, is known to play a major role in liver regeneration, as well as in carcinogenesis (39). This cytokine has been shown to modulate the effects of AHR ligands on proliferation and the expression of cytochrome P450 enzymes in rat liver 'stem-like' cells (39). AHR signaling causes NF- $\kappa B$ Rel B activation during dendritic-cell differentiation (43). Moreover, TCDD induces hepatic stellate cell activation and liver fibrosis in C57BL/6 mice by activating the Akt and NF- $\mathrm{KB}$ signaling pathways (44). In the present study, TNF- $\alpha$ suppressed the proliferation and stimulated the death of HepG2 cells in vitro; however, the suppressive effects of TCDD on the proliferation of and its promoting effects on the death of HepG2 cells were not potentiated by TNF- $\alpha$. We also demonstrated that TCDD 
increased NF- $\mathrm{BB}$ p65 expression in HepG2 cells in vitro. These observations indicate that the effects of TCDD may be partly mediated through the activation of $\mathrm{NF}-\kappa \mathrm{B}$ signaling.

TCDD has been shown to increase Ras expression in studies using transcriptomics and metabonomics to unravel modes of action of TCDD in HepG2 cells in vitro (45). In the present study, TCDD was also found to increase the levels of $\beta$-catenin, STAT3, Ras and Akt, all of which are involved in cell proliferation and differentiation $(32,41)$, in HepG2 cells. These molecules may be partly involved in mediating the effects of TCDD on the proliferation and death of HepG2 cells. Importantly, we found that TCDD increased the levels of p53, $\mathrm{Rb}, \mathrm{p} 21$ and regucalcin, which each play roles as suppressors of the growth of tumor cells $(40,41) . \beta$-catenin has been reported to increase regucalcin expression in HepG2 cells in vitro (46). The overexpression of regucalcin has been shown to elevate the levels of p53, Rb and p21 in HepG2 cells in vitro (47). It is possible that these molecules are partly involved in mediating the effects of TCDD on the proliferation and death of HepG2 cells. It remains to be elucidated, however, whether or not the TCDD-induced enhancement of these molecules results from the activation of AHR signaling.

Gemcitabine, an antitumor drug, is known to suppress the proliferation and stimulate the death of cancer cells by inducing nuclear DNA damage (42), although this drug may not be linked to AHR signaling. Of note, the suppressive effects of TCDD on the proliferation and its promoting effects on the death of HepG2 cells, were significantly potentiated by gemcitabine. This suggests that the mode of action of TCDD on cell proliferation and death differs from that of gemcitabine. TCDD has been demonstrated to activate AHR signaling and thereby regulate the expression of diverse molecules (1-4). The combination of TCDD and gemcitabine may exert a potent antitumor effect, suggesting a novel strategy for cancer therapy.

In conclusion, the findings of the present study demonstrate that TCDD suppresses the growth of human liver cancer HepG2 cells in vitro, suppressing colony formation and proliferation and stimulating death, via various signaling pathways. TCDD at a comparatively low dose may exert an antitumor effect in vivo, suggesting a novel strategy for cancer therapy.

\section{Acknowledgements}

Not applicable.

\section{Funding}

This study was supported in part from NIH grant 1RO1ES024434 (O.H.).

\section{Availability of data and materials}

The datasets used during the present study are available from the corresponding author upon reasonable request.

\section{Authors' contributions}

MY conceived and designed the study. MY and $\mathrm{OH}$ performed the experiments and discussed the findings. MY wrote the manuscript, and $\mathrm{OH}$ edited the manuscript. Both authors have read and approved the manuscript and agree to be accountable for all aspects of the research in ensuring that the accuracy or integrity of any part of the work are appropriately investigated and resolved.

\section{Ethics approval and consent to participate}

Not applicable.

\section{Patient consent for publication}

Not applicable.

\section{Competing interests}

The authors declare that they have no competing interests.

\section{References}

1. Hankinson O: The aryl hydrocarbon receptor complex. Annu Rev Pharmacol Toxicol 35: 307-340, 1995.

2. Hankinson O: Role of coactivators in transcriptional activation by the aryl hydrocarbon receptor. Arch Biochem Biophys 433: 379-386, 2005.

3. Kamenickova A, Anzenbacherova E, Pavek P, Soshilov AA, Denison MS, Anzenbacher P and Dvorak Z: Pelargonidin activates the AhR and induces CYP1A1 in primary human hepatocytes and human cancer cell lines HepG2 and LS174T. Toxicol Lett 218: 253-259, 2013

4. Kamenickova A, Anzenbacherova E, Pavek P, Soshilov AA, Denison MS, Zapletalova M, Anzenbacher P and Dvorak Z: Effects of anthocyanins on the AhR-CYP1A1 signaling pathway in human hepatocytes and human cancer cell lines. Toxicol Lett 221: 1-8, 2013.

5. Dvorak Z, Vrzal R, Henklova P, Jancova P, Anzenbacherova E, Maurel P, Svecova L, Pavek P, Ehrmann J, Havlik R, et al: JNK inhibitor SP600125 is a partial agonist of human aryl hydrocarbon receptor and induces CYP1A1 and CYP1A2 genes in primary human hepatocytes. Biochem Pharmacol 75: 580-588, 2008.

6. Pastorková B, Vrzalová A, Bachleda $\mathrm{P}$ and Dvořák Z: Hydroxystilbenes and methoxystilbenes activate human aryl hydrocarbon receptor and induce CYP1A genes in human hepatoma cells and human hepatocytes. Food Chem Toxicol 103: 122-132, 2017.

7. Palermo CM, Hernando JI, Dertinger SD, Kende AS and Gasiewicz TA: Identification of potential aryl hydrocarbon receptor antagonists in green tea. Chem Res Toxicol 16: 865-872, 2003.

8. Go RE, Hwang KA and Choi KC: Cytochrome P450 1 family and cancers. J Steroid Biochem Mol Biol 147: 24-30, 2015.

9. Stejskalova L and Pavek P: The function of cytochrome P450 1A1 enzyme (CYP1A1) and aryl hydrocarbon receptor (AhR) in the placenta. Curr Pharm Biotechnol 12: 715-730, 2011.

10. Forrester AR, Elias MS, Woodward EL, Graham M, Williams FM and Reynolds NJ: Induction of a chloracne phenotype in an epidermal equivalent model by 2,3,7,8-tetrachlorodibenzo-p-dioxin (TCDD) is dependent on aryl hydrocarbon receptor activation and is not reproduced by aryl hydrocarbon receptor knock down. J Dermatol Sci 73: 10-22, 2014.

11. Pierre S, Chevallier A, Teixeira-Clerc F, Ambolet-Camoit A, Bui LC, Bats AS, Fournet JC, Fernandez-Salguero P, Aggerbeck M, Lotersztajn S, et al: Aryl hydrocarbon receptor-dependent induction of liver fibrosis by dioxin. Toxicol Sci 137: 114-124, 2014.

12. Wu D, Nishimura N, Kuo V, Fiehn O, Shahbaz S, Van Winkle L, Matsumura F and Vogel CF: Activation of aryl hydrocarbon receptor induces vascular inflammation and promotes atherosclerosis in apolipoprotein $\mathrm{E}^{-/-}$mice. Arterioscler Thromb Vasc Biol 31: 1260-1267, 2011.

13. Roh E, Kwak SH, Jung HS, Cho YM, Pak YK, Park KS, Kim SY and Lee HK: Serum aryl hydrocarbon receptor ligand activity is associated with insulin resistance and resulting type 2 diabetes. Acta Diabetol 52: 489-495, 2015. 
14. Brito JS, Borges NA, Esgalhado M, Magliano DC, Soulage CO and Mafra D: Aryl hydrocarbon receptor activation in chronic kidney disease: Role of uremic toxins. Nephron 137: 1-7, 2017.

15. Esser C: The aryl hydrocarbon receptor in immunity: Tools and potential. Methods Mol Biol 1371: 239-257, 2016.

16. Murray IA, Patterson AD and Perdew GH: Aryl hydrocarbon receptor ligands in cancer: Friend and foe. Nat Rev Cancer 14: 801-814, 2014.

17. Nukaya M, Moran S and Bradfield CA: The role of the dioxin-responsive element cluster between the Cyp1a1 and Cypla2 loci in aryl hydrocarbon receptor biology. Proc Natl Acad Sci USA 106: 4923-4928, 2009.

18. Uno S, Dalton TP, Sinclair PR, Gorman N, Wang B, Smith AG, Miller MI, Shertzer HG and Nebert DW: Cyp1a1(-/-) male mice: Protection against high-dose TCDD-induced lethality and wasting syndrome, and resistance to intrahepatocyte lipid accumulation and uroporphyria. Toxicol Appl Pharmacol 196: 410-421, 2004.

19. Singh KP, Garrett RW, Casado FL and Gasiewicz TA: Aryl hydrocarbon receptor-null allele mice have hematopoietic stem/ progenitor cells with abnormal characteristics and functions. Stem Cells Dev 20: 769-784, 2011.

20. Barouki R, Coumoul X and Fernandez-Salguero PM: The aryl hydrocarbon receptor, more than a xenobiotic-interacting protein. FEBS Lett 581: 3608-3615, 2007.

21. Mulero-Navarro S and Fernandez-Salguero, PM: New trends in aryl hydrocarbon receptor biology. Front Cell Dev Biol 4: 45, 2016.

22. Moennikes O, Loeppen S, Buchmann A, Andersson P, Ittrich C, Poellinger L and Schwarz M: A constitutively active dioxin/aryl hydrocarbon receptor promotes hepatocarcinogenesis in mice. Cancer Res 64: 4707-4710, 2004.

23. Fan Y, Boivin GP, Knudsen ES, Nebert DW, Xia Y and Puga A: The aryl hydrocarbon receptor functions as a tumor suppressor of liver carcinogenesis. Cancer Res 70: 212-220, 2010.

24. Corchero J, Martín-Partido G, Dallas SL and FernándezSalguero PM: Liver portal fibrosis in dioxin receptor-null mice that overexpress the latent transforming growth factor-beta-binding protein-1. Int J Exp Pathol 85: 295-302, 2004.

25. Schmidt JV, Su GH-T, Reddy JK, Simon MC and Bradfield CA Characterization of a murine Ahr null allele: Involvement of the Ah receptor in hepatic growth and development. Proc Natl Acad Sci USA 93: 6731-6736, 1996.

26. Lahvis GP, Lindell SL, Thomas RS, McCuskey RS, Murphy C, Glover E, Bentz M, Southard J and Bradfield CA: Portosystemic shunting and persistent fetal vascular structures in aryl hydrocarbon receptor-deficient mice. Proc Natl Acad Sci USA 97: 10442-10447, 2000

27. Jackson DP, Li H, Mitchell KA, Joshi AD and Elferink CJ: Ah receptor-mediated suppression of liver regeneration through NC-XRE-driven p21Cip1 expression. Mol Pharmacol 85: 533-541, 2014.

28. Mathew LK, Simonich MT and Tanguay RL: AHR-dependent misregulation of Wnt signaling disrupts tissue regeneration. Biochem Pharmacol 77: 498-507, 2009.

29. Moreno-Marín N, Barrasa E, Morales-Hernández A, Paniagua B, Blanco-Fernández G, Merino JM and Fernández-Salguero PM: Dioxin receptor adjust liver regeneration after acute toxic injury and protects against liver carcinogenesis. Sci Rep 7: 10420, 2017.

30. Knowles BB, Howe CC and Aden DP: Human hepatocellular carcinoma cell lines secrete the major plasma proteins and hepatitis B surface antigen. Science 209: 497-499, 1980.

31. Choi EY, Lee H, Dingle RWC, Kim KB and Swanson HI: Development of novel CH223191-based antagonists of the aryl hydrocarbon receptor. Mol Pharmacol 81: 3-11, 2012.
32. Fang Z, Tang Y, Fang J, Zhou Z, Xing Z, Guo Z, Guo X, Wang W, Jiao W, Xu Z and Liu Z: See comment in PubMed Commons belowSimvastatin inhibits renal cancer cell growth and metastasis via AKT/mTOR, ERK and JAK2/STAT3 pathway. PLoS One 8: e62823, 2013.

33. Wang K, Li Y, Jiang YZ, Dai CF, Patankar MS, Song JS and Zheng J: An endogenous aryl hydrocarbon receptor ligand inhibits proliferation and migration of human ovarian cancer cells. Cancer Lett 340: 63-71, 2013.

34. Yamaguchi $M$ and Daimon Y: Overexpression of regucalcin suppresses cell proliferation in cloned rat hepatoma H4-II-E cells: Involvement of intracellular signaling factors and cell cycle-related genes. J Cell Biochem 95: 1169-1177, 2005.

35. Izumi $\mathrm{T}$ and Yamaguchi M: Overexpression of regucalcin suppresses cell death in cloned rat hepatoma H4-II-E cells induced by tumor necrosis factor-alpha or thapsigargin. J Cell Biochem 92: 296-306, 2004.

36. Yamaguchi M, Osuka S, Weitzmann MN, El-Rayes BF, Shoji M and Murata T: Prolonged survival in pancreatic cancer patients with increased regucalcin gene expression: Overexpression of regucalcin suppresses the proliferation in human pancreatic cancer MIA PaCa-2 cells in vitro. Int J Oncol 48: 1955-1964, 2016.

37. Yamaguchi M and Isogai M: Tissue concentration of calcium-binding protein regucalcin in rats by enzyme-linked immunoadsorbent assay. Mol Cell Biochem 122: 65-68, 1993.

38. Vaziri C, Schneider A, Sherr DH and Faller DV: Expression of AHR is regulated by serum and mitogenic growth factors in murine 3T3 fibroblasts. J Biol Chem 271: 25921-25927, 1996.

39. Umannová L, Zatloukalová J, Machala M, Krcmár P, Májková Z, Hennig B, Kozubík A and Vondrácek J: Tumor necrosis factor- $\alpha$ modulates effects of aryl hydrocarbon receptor ligands on cell proliferation and expression of cytochrome P450 enzymes in rat liver 'stem-like' cells. Toxicol Sci 99: 79-89, 2007.

40. Tsurusaki Y and Yamaguchi M: Role of regucalcin in liver nuclear function: Binding of regucalcin to nuclear protein or DNA and modulation of tumor-related gene expression. Int J Mol Med 14: 277-281, 2004.

41. Yamaguchi M: Suppressive role of regucalcin in liver cell proliferation: Involvement in carcinogenesis. Cell Prolif 46: 243-253, 2013.

42. Tang SC and Chen YC: Novel therapeutic targets for pancreatic cancer. World J Gastroenterol 20: 10825-10844, 2014.

43. Vogel CFA, Wu D, Goth SR, Baek J, Lollies A, Domhardt R, Grindel A and Pessah IN: Aryl hydrocarbon receptor signaling regulates NF- $\mathrm{KB}$ RelB activation during dendritic-cell differentiation. Immunol Cell Biol 91: 568-575, 2013.

44. Han M, Liu X, Liu S, Su G, Fan X, Chen J, Yuan Q and Xu G: 2,3,7,8-Tetrachlorodibenzo- $p$-dioxin (TCDD) induces hepatic stellate cell (HSC) activation and liver fibrosis in C57BL6 mouse via activating Akt and NF-kB signaling pathways. Toxicol Lett 273: 10-19, 2017.

45. Jennen D, Ruiz-Aracama A, Magkoufopoulou C, Peijnenburg A, Lommen A, van Delft J and Kleinjans J: Integrating transcriptomics and metabonomics to unravel modes-of-action of 2,3,7,8-tetrachlorodibenzo-p-dioxin (TCDD) in HepG2 cells. BMC Syst Biol 5: 139, 2011.

46. Nejak-Bowen KN, Zeng G, Tan X, Cieply B and Monga SP: Beta-catenin regulates vitamin $\mathrm{C}$ biosynthesis and cell survival in murine liver. J Biol Chem 284: 28115-28127, 2009.

47. Yamaguchi M, Osuka S, Weitzmann MN, El-Rayes BF, Shoji M and Murata T: Prolonged survival in hepatocarcinoma patients with increased regucalcin gene expression: HepG2 cell proliferation is suppressed by overexpression of regucalcin in vitro. Int J Oncol 49: 1686-1694, 2016. 